\title{
UFRS 16 Kiralamalar Standardının Kiracının Finansal Tabloları Üzerine Etkileri: Seçilmiş Hava Yolu İşletmelerinde Bir İnceleme \\ (Effects of IFRS 16 Leases Standard on Financial Statements of Lessee: An Analysis on Selected Airline Companies)
}

\section{Soner GÖKTEN iD a Gül ARSLAN KURNAZ iD b}

a Başkent Üniversitesi, İktisadi ve İdari Bilimler Fakültesi, İşletme Bölümü, Ankara, Türkiye. sgokten@baskent.edu.tr

b Yeminli Mali Müşavir, Bağımsız Denetçi. gulkurnazarslan@gmail.com

\begin{tabular}{|c|c|}
\hline MAKALE BİLGİSİ & ÖZET \\
\hline Anahtar Kelimeler: & Amaç - Bu çalışmanın amacı, kiralama işlemlerinin muhasebesinde ve raporlanmasında UMS 17 \\
\hline Finansal Tablo & yerine uygulanmaya başlayan UFRS $16^{\prime}$ nın kiracının finansal tabloları, oranları ve göstergeleri \\
\hline Kiralama & üzerindeki etkisini incelemektir. Çalışmada, yüksek hacimde faaliyet kiralaması gerçekleştiren hava \\
\hline UFRS 16 & yolu işletmelerinin kamuya açık finansal raporları kullanılmıştır. \\
\hline Uluslararası Finansal & Yöntem - Çalışmada analitik karşılaştırma ve oran analizi yöntemleri benimsenmiştir. Öncelikle \\
\hline Raporlama Standartları & $\begin{array}{l}\text { UFRS } 16 \text { 'nın kiracının finansal tabloları, oranları ve göstergeleri üzerinde yaratması beklenen } 17 \\
\text { farklı etki tanımlanmıştır. Sonrasında Türk Hava Yolları'nın, Pegasus Hava Yolları'nın, Lutfhansa }\end{array}$ \\
\hline $\begin{array}{l}\text { Gönderilme Tarihi } 25 \text { Nisan } \\
2020\end{array}$ & $\begin{array}{l}\text { Hava Yolları'nın ve İskandinav Hava Yolları'nın ilk kez UFRS } 16 \text { 'ya uygun olarak yayınlanan } \\
\text { finansal raporları vasıtasıyla beklentilerin ne ölçüde gerçekleştiği değerlendirilmiştir. }\end{array}$ \\
\hline $\begin{array}{l}\text { Revizyon Tarihi } 2 \text { Haziran } \\
2020\end{array}$ & $\begin{array}{l}\text { Bulgular - Sonuçlar, beklenen etkilerin neredeyse tamamının gerçekleştiğini ortaya koymaktadır. } \\
\text { Beklentilerle ters yöndeki gerçekleşmeler, esas itibariyle UFRS } 16 \text { kaynaklı değildir. }\end{array}$ \\
\hline Kabul Tarihi 15 Haziran 2020 & $\begin{array}{l}\text { Tartışma - Elde edilen bulgular UFRS } 16^{\prime} \text { nın işletmelerin sermaye ve kar yapılarında değişiklikler } \\
\text { yarattığını göstermektedir. Diğer unsurlar sabit kalmak şartıyla UFRS 16, yüksek hacimde faaliyet }\end{array}$ \\
\hline $\begin{array}{l}\text { Makale Kategorisi: } \\
\text { Araştırma Makalesi }\end{array}$ & $\begin{array}{l}\text { kiralaması yapılan sektörlerdeki işletmelerin piyasa değeri/defter değeri oranlarının yükselmesine } \\
\text { neden olacaktır. Ayrıca, kiracı işletmelerin hem kısa hem de uzun vadeli finansal risklilikleri } \\
\text { artırmakta, varlık etkinliğinin ise düşük görünmesine yol açmaktadır. }\end{array}$ \\
\hline
\end{tabular}

\begin{tabular}{|c|c|}
\hline ARTICLE INFO & ABSTRACT \\
\hline $\begin{array}{l}\text { Keywords: } \\
\text { Financial Statement } \\
\text { Lease } \\
\text { IFRS } 16\end{array}$ & $\begin{array}{l}\text { Purpose - The aim of this study is to examine the effect of IFRS 16, which started to be applied } \\
\text { instead of IAS } 17 \text { in the accounting and reporting of lease transactions, on the financial statements, } \\
\text { ratios and indicators of the lessee. Financial reports of the airline companies that have a high volume } \\
\text { of operational leases have been used in this paper. }\end{array}$ \\
\hline $\begin{array}{l}\text { International Financial } \\
\text { Reporting Standards }\end{array}$ & $\begin{array}{l}\text { Design/methodology/approach - Analytical comparison and ratio analysis methods were adopted } \\
\text { in the study. In the first step, } 17 \text { different effects are identified which are expected to have an impact } \\
\text { on lessee's financial statements, ratios and indicators because of IFRS } 16 \text {. Then the financial reports } \\
\text { of Turkish Airlines, Pegasus Airlines, Lufthansa Airlines and Scandinavian Airlines which were }\end{array}$ \\
\hline $\begin{array}{l}\text { Received } 25 \text { April } 2020 \\
\text { Revised } 2 \text { Haziran } 2020\end{array}$ & $\begin{array}{l}\text { published in compliance with IFRS } 16 \text { were examined in order to see whether the expectations are } \\
\text { met or not. }\end{array}$ \\
\hline Accepted 15 Haziran 2020 & $\begin{array}{l}\text { Findings - The results reveal that almost all of the expected effects occur. Findings which are } \\
\text { contrary to expectations are not mainly due to IFRS } 16 \text {. }\end{array}$ \\
\hline $\begin{array}{l}\text { Article Classification: } \\
\text { Research Article }\end{array}$ & $\begin{array}{l}\text { Discussion - The findings show that IFRS } 16 \text { creates changes in the capital and profit structures of } \\
\text { enterprises. When other factors remain constant IFRS } 16 \text { will cause higher market value/book value } \\
\text { ratios for businesses in high volume operating leases. In addition, IFRS } 16 \text { increases both short and } \\
\text { long term financial risks of lessee enterprises and cause asset efficiency to appear low. }\end{array}$ \\
\hline
\end{tabular}

\section{Önerilen Atıf/Suggested Citation}

Gökten, S., Arslan Kurnaz, G. (2020). UFRS 16 Kiralamalar Standardının Kiracının Finansal Tabloları Üzerine Etkileri: Seçilmiş Hava Yolu İşletmelerinde Bir İnceleme, İşletme Araştırmaları Dergisi, 12 (2), 1848-1860. 


\section{S. Gökten - G. Arslan Kurnaz 12/2 (2020) 1848-1860}

\section{GİRIŞ}

13 Ocak 2016 tarihinde yayımlanan 16 numaralı 'Kiralamalar' isimli Uluslararası Finansal Raporlama Standardı (UFRS 16) 1 Ocak 2019 tarihinden başlayan hesap dönemlerinde zorunlu olarak uygulanmak üzere yürürlüğe girmiştir. Bu tarihten önceki hesap dönemlerinde uygulamak isteğe bağlı olup dipnotlarda belirtilmek suretiyle, söz konusu standart uygulanabilmiştir. UFRS 16'nın yürürlüğe girmesinden önce uygulanan 17 numaralı 'Kiralama İşlemleri' isimli Uluslararası Muhasebe Standardı (UMS 17) faaliyet kiralamalarını finansal tablo dışında bırakmıştır. Bu durum, finansal durum tablolarında işletmelerin faaliyet kiralamalarından kaynaklanan hak ve yükümlülüklerinin gösterilmemesi nedeniyle gerçeğe uygun sunum ilkesine uyumda sınıktılar meydana getirmiştir. Bu sıkıntıların çözümlenmesi amacıyla UFRS 16 UMS 17 yerine uygulanmak üzere yürürlüğe girmiştir. Özellikle kiralayanlar açısından faaliyet kiralamalarının hak ve yükümlülük olarak finansal tablolarda raporlanması, finansal tabloların daha şeffaf, açık ve güvenilir olmasını sağlayacaktır.

UMS 17 çerçevesince finansal tablo dışında kalan faaliyet kiralamalarının UFRS 16 ile finansal tablolara alınması, işletmelerin finansal tablolarında yapısal değişimler meydana getirecektir (Aktaş ve diğerleri, 2017). Kiralama işlemlerinin konusunu oluşturan varlıkların finansal durum tablosunda kullanım hakkı olarak duran varlıklar içerisinde, buna karşın kiralama süresi boyunca katlanılacak olan kira giderlerinin yükümlülük içerisinde raporlanacak olması özellikle faaliyet kiralamasının yoğun olduğu işletmelerde finansal durum tabloları üzerinde ciddi etkiler yaratacaktır. Faaliyet kiralamalarına ilişkin kira giderlerinin doğrudan gider yazılmayarak, amortisman yolu ile itfa edilmesi nedeniyle amortisman giderlerinde ve kira yükümlülükleri nedeniyle faiz giderlerinde artışlar olması muhtemeldir.

Hava yolu işletmelerinin uçak filolarının önemli bir kısmını faaliyet kiralaması çerçevesinde temin ettikleri bilinmektedir. Dolayısıyla, UFRS 16 uygulamasıyla beraber özellikle hava yolu işletmelerinin finansal tablolarının etkileneceği beklenmektedir. Bu nedenle çalışmamızda Türk Hava Yolları (THY), Pegasus Hava Yolları (PHY), Lutfhansa Hava Yolları (LHY) ve İskandinav Hava Yolları (IHHY) olmak üzere dört hava yolu işletmesinin UFRS 16'ya göre hazırlanan finansal tabloları incelenmiştir. UFRS 16'nın kiracının finansal tabloları üzerindeki öncül etkileri öncelikle beklenti olarak ortaya konulmuş, sonrasında ise gerçekleşen etkiler değerlendirilmiştir. Çalışmada analitik karşılaştırma ve oran analizi yöntemleri benimsenmiştir.

Çalışma şu şekilde kurgulanmıştır: İkinci bölümde standartlar kapsamında kiralama işlemi açıklanmış ve kiralama işleminin UFRS 16'ya göre ne şekilde muhasebeleştirilmesi gerektiği gösterilmiştir. Üçüncü bölümde, UFRS 16 uygulamasına geçişin kiracının finansal tabloları ile finansal oranları ve göstergeleri üzerindeki öncül beklenen etkileri ortaya konulmuştur. Bu bölümde sunulan öncül beklentilerin her biri çalışmada sunulan birer hipotezdir. Dördüncü bölümde, seçilmiş havayolu işletmelerinin bağımsız denetim raporları incelenerek her bir havayolu için belirtilen öncül beklentilerin gerçekleşip gerçekleşmediği, diğer bir ifadeyle çalışmanın bulguları sunulmuştur. Takip eden bölümde çalışma sonlandırılmıştır.

\section{KİRALAMA İŞLEMİ VE UFRS 16'YA GÖRE MUHASEBELEŞTİRILMESİ}

Kiralama işleminin söz konusu olabilmesi için kiralama konusu bir varlığın mevcut olması ve belirli bir süre için bir bedel karşıllğı kullanımının kiralayana bırakılması gerekmektedir. Kiralama işlemleri faaliyet kiralaması ve finansal kiralama olmak üzere iki başlık altında sınıflandırılmıştır. Bunlara ek olarak, bir finansman yöntemi olan sat ve geri kirala işlemleri de hibrit bir kiralama şekli olarak karşımıza çıkmaktadır.

UFRS 16' da 'Kiralamaların Sınıflandırılması' Bölümü 62. paragrafta 'dayanak varlı̆gı mülkiyetinden kaynaklanan tüm risk ve getirilerin önemli ölçüde devredilmediği' kiralamalar faaliyet kiralaması olarak tanımlanmıştır (TFRS16, 2018, s.9). Tanımın özü değerlendirildiğinde, varlığın hukuki mülkiyetinin kiraya verende kaldığı, kullanım hakkının devredildiği, kiralama süresinin varlığın ekonomik ömrünü doldurmayacak bir zaman dilimi için belirlendiği ve kira süresinin sonunda varlığın düşük bedelle devredilmesinin öngörülmediği kiralamaların faaliyet kiralaması olarak ifade edildiği anlaşılmaktadır.

6361 Sayılı Finansal Kiralama, Faktoring ve Finansman Şirketleri Kanunu'nun 3. Madde ç bendinde finansal kiralama, 'Bir finansal kiralama sözleşmesine dayalı olmak koşuluyla, bu Kanun veya ilgili mevzuatı uyarınca yetkilendirilen kiralayan tarafından finansman sağlamaya yönelik olarak bir malın mülkiyetinin kira süresi sonunda kiracıya devredilmesi; kiracıya kira süresi sonunda malın rayiç bedelinden düşük bir bedelle satın alma hakkı tanınması; kiralama süresinin maln ekonomik ömrünün yüzde sekseninden daha büyük bir bölümünü kapsaması veya finansal 


\section{S. Gökten - G. Arslan Kurnaz 12/2 (2020) 1848-1860}

kiralama sözleşmesine göre yapılacak kira ödemelerinin bugünkü değerlerinin toplamının malın rayiç bedelinin yüzde doksanından daha büyük bir değeri oluşturması hâllerinden herhangi birini să̆layan kiralama işlemi' olarak tanımlanmıştır.

UFRS 16 ise şekilden ziyade öze ağırlık vermiş ve 'Kiralamaların Sınıflandırılması Bölümü' 63. ve 64 . paragraflarda bir kiralamanın finansal kiralama olarak sınıflandırılabilmesi için aşağıda yer alan hususlardan birinin dahi olması yeterli görülmüştür (TFRS16, 2018, s.9).

- Varlığın mülkiyeti nedeniyle oluşacak tüm risk ve getirilerin önemli ölçüde kiracıya devredilmesi,

- Varlığın mülkiyetinin kiralama süresi sonunda kiracıya devredilmesinin öngörülmesi,

- Kiracıya varlığın gerçeğe uygun değerinden düşük bir bedelle devredilmesi konusunda seçenek sunulması ve kira başlangıç tarihinde kiracının bu seçeneği kullanacağı konusunda makul derecede emin olunması,

- Kira süresi sonunda varlığın mülkiyeti devredilmese dahi, kiralama süresinin varlığın ekonomik ömrünün büyük bir bölümünü içermesi,

- Kiranın bugünkü değerinin varlığın gerçeğe uygun değerinin tamamına yakın olması,

- Varlığın sadece kiracının kullanabileceği özel bir yapıda olması,

- Kiracı tarafından kira sözleşmesinin feshedilmesi durumunda, fesih sonucu ortaya çıkan zararı kiracının karşılaması,

- Varlığın yararlı ömrünün sonunda elden çıkarma maliyeti düşülmüşs satış fiyatının, gerçeğe uygun değerinde oluşabilecek kar veya zararın kiracının olması,

- Kiracının kira süresinin sonunda ikinci bir dönem için piyasa fiyatının önemli düzeyde altında kiralamayı devam ettirme hakkının bulunması.

Bu bakımdan UFRS 16 ile 6361 sayılı Kanunda yer alan finansal kiralama tanımları birbirinden farklılıklar göstermektedir. UFRS 16' da, kiraya verenin finansal kiralama şirketi olması şartı mevcut değildir. Öte yandan, 6361 sayılı Kanunda yer alan kira süresinin varlığın ekonomik ömrünün \%80'inden fazla olması şartı UFRS 16 'da bulunmamaktadır. UFRS 16'da kiralama süresinin kiralama işlemine konu olan varlığın ekonomik ömrünün büyük bir kısmını kapsaması yeterli görülmüştür. Ayrıca, 6361 sayılı Kanunda yer alan kira ödemelerinin bugünkü değerinin kiralama konusu varlığın rayiç bedelinin \% 90'ından büyük olması şartı, UFRS 16 da yer almamaktadır.

Kiralama işlemlerinin finansal tablolara alınmasında öncelikli olarak kiralama işleminin tanımlanması gerekmektedir. UFRS 16'nın 'Kiralamanın Tanımlanması Bölümü 9. paragrafta 'kiralamanın tanımlanmasında öncelikle bir sözleşmenin kiralama sözleşmesi olup olmadı̆̆ veya kiralama işlemi içerip içermediğinin değerlendirilir. Sözleşmenin, bir bedel karşılığında tanımlanan varlı̆̆ın kullanımın kontrol etme hakkını belirli bir süre için devretmesi durumunda bu sözleşme, bir kiralama sözleşmesidir ya da bir kiralama işlemi içerir' denilmektedir (TFRS 16, 2018, s.3). Ayrıca bir sözleşmenin tanımlanan bir varlığın kullanımını kontrol etme hakkını belirli bir süre için devredip devretmediğini değerlendirmek için, kiracının kullanım süresi boyunca şu iki hakka da sahip olması gerekmektedir: Tanımlanan varlığın kullanımından sağlanacak ekonomik yararların tamamına yakınını elde etme hakkı ve tanımlanan varlığın kullanımını yönetme hakkı (TFRS 16, 2018, s.19). Bu bağlamda, UFRS 16'ya göre kiracının varlığı kullandığı sürede varlığın kullanımından sağlanan ekonomik faydalarının tamamına yakınını elde etme hakkı var ancak yönetme hakkı yoksa bu işlem kiralama içermemektedir. Öte yandan, kiracı kiralama süresi boyunca kiralama konusu varlığı nasıl ve hangi amaçla kullanacağını belirlememişse yine herhangi bir kira işleminden bahsedilmez.

Örneğin, fiber kablo altyapısına sahip A işletmesi ile B servis sağlayıcısı belirli bir bölgedeki fiber bağlantının belirli bir kapasitesinden B işletmesinin faydalandırılması amacıyla sözleşme yapıyor olsunlar. Sözleşme gereği iki yıl boyunca B işletmesi, fiber veri akışının tüm yönleriyle ne şekilde yapılacağına A işletmesinin karar vermesi şartıyla fiber altyapıdan faydalanacaktır. Bu sözleşme kapsamında B işletmesi sözleşme süresi boyunca fayda elde etse de; fiber altyapısı üzerindeki kullanımı yönetme hakkı bulunmadığında sözleşme kiralama işlemi içermemektedir. Diğer taraftan, örneğin bir hava taksi işletmesiyle X gerçek kişisi arasında mülkiyeti $X$ şahsında bulunan bir iş jetinin iki yıl süresince hava taksi işletmesi tarafından işletilmesine yönelik olarak bir sözleşme düzenleniyor. Bu sözleşmede uçağın özellikleri detaylı şekilde tanımlanmakta ve uçağın işletilmesine ilişkin yasal sınırlılıklar belirtilmektedir. Söz konusu sınırlılıklar haricinde hava taksi işletmesi uçağın ne zaman ve nereye uçacağı hususunda yetkilidir. Bu sözleşme değerlendirildiğinde hava taksi 


\section{S. Gökten - G. Arslan Kurnaz 12/2 (2020) 1848-1860}

işletmesi elde edeceği ekonomik faydanın yanı sıra uçağın kullanımını yönetme hakkına sahiptir. Bu nedenle bu sözleşme bünyesinde kiralama işlemi barındırmaktadır.

UMS 17 ile karşılaştırıldığında UFRS 16 esasen kiralama işlemlerinin faaliyet mi yoksa finansal kiralama mı olduğuna değil, kiralama işlemenin var olup olmadığına odaklanmıştır. Çünkü UFRS 16 çerçevesinde faaliyet kiralamaları da finansal kiralamalarla benzer şekilde raporlamaya tabi tutulmuştur. Diğer bir ifadeyle UFRS 16 çerçevesince öncelikle kiralama işleminin mevcudiyeti tespit edilmelidir ve kiralamanın mevcudiyeti için kiracının detayları tanımlanmış varlığın kullanım hakkından fayda elde ediyor ve kullanım hakkına ilişkin yönetme hakkını elinde bulunduruyor olması gerekmektedir.

Kiralama işlemlerinin kayıtlara alınmasında kiracının elde ettiği kullanım hakkının değeri kira tutarlarının bugünkü değerine eşittir. Belirlenebiliyorsa zımmi faiz oranı, aksi takdirde kiracının alternatif borçlanma faiz oranı esas alınarak kira bedelleri iskonto edilir. Varlıklar içerisinde haklarda raporlanan bu değerin karşılığı yükümlülüklerde yer alacaktır. UFRS 16 ‘Kullanım Hakkı Varlığının Ölçümü Bölümü' 27. Paragrafta ifade edildiği şekliyle, kiralamanın fiilen başladığı tarihte ödenmemiş ve kiracının finansal tablolarında yükümlülük olarak yer alacak kira bedellerinin hangi ödemelerden oluştuğunu aşağıda belirtilmiştir (TFRS 16, 2018, s.5).

- Sabit ödemelerden her türlü kiralama teşvik alacaklarının düşülmesiyle bulunan tutar,

- Ilk ölçümü kiralamanın fiilen başladığı tarihte bir endeks veya oran kullanılarak yapılan, bir endeks veya orana bağlı değişken kira ödemeleri,

- Kalıntı değer taahhütleri kapsamında kiracı tarafindan ödenmesi beklenen tutarlar,

- Kiracının satın alma opsiyonunu kullanacağından makul ölçüde emin olması durumunda, bu opsiyonun kullanım fiyatı

- Kiralama süresinin kiracının kiralamayı sonlandırmak için bir opsiyon kullanacağını göstermesi durumunda, kiralamanın sonlandırılmasına ilişkin ceza ödemeleri.

Ayrıca, UFRS 16 24. paragrafta, kiracının kiralama işlemi sonucu kullanım hakkının finansal tablolara alınmasında yükümlülüğün ilk ölçüm tutarının, kiralamanın fiilen başladığı tarih veya bu tarihten önce ödenen kira bedellerinden alınan tüm teşviklerin düşülmesi sonucu kalan tutarın, kiralama sözleşmesinin yapılması nedeniyle katlanılan ek maliyetlerin ve kiralama konusu varlığın taşınması, sökülmesi, yeniden kurulması, onarımı vb. yapılan tahmini maliyetlerin finansal tabloları yansıtılması gerektiği belirtmektedir (TFRS 16, 2018, s4). UFRS 16 uhdesinde yer alan ilk muhasebeleştirmeye ilişkin ilkeler çerçevesinde muhasebe kayıtları aşağıdaki örnekte sunulduğu gibi yapılabilecektir.

İlk Muhasebeleştirme Örneği: ABC işletmesi, idari merkez olarak kullanmak amacıyla 1.1.2020 tarihinden başlamak üzere 10 yıl süreyle ve yıllık 100.000 TL (enflasyona dayalı artışlar göz ardı edilmiştir) kira bedeliyle bir ofis kiralamıştır. Kullanım hakkını elde etmek için 17.500 TL eski kiracıya ve 12.500 TL emlak danışmanına olmak üzere toplam 30.000 TL komisyon harcamasına katlanmıştır. Sözleşme gereği, ilk kira ödemesi peşin yapılmış olup, gelecek kira taksitlerinin ödemesi her yılın ilk iş gününde yapılacaktır. Alternatif borçlanma maliyeti (piyasa faiz oranı) \%10 olarak tespit edilmiştir. Kiralanan varlık sözleşme sonunda kiracıya devredilmeyecek olup, varlığın ekonomik ömrü 50 yıldır.

Öncelikle kira ödemelerinin bugünkü değeri tespit edilmelidir. BD: bugünkü değer, C: kira ödemeleri (taktiler), r: Alternatif borçlanma (piyasa faiz) oranı ve i: vade olmak üzere bugünkü değer aşağıdaki şekilde hesaplanmaktadır.

$B D=C\left[\frac{1}{r}-\frac{1}{r(1+r)^{i}}\right]+100.000=100.000\left[\frac{1}{0,10}-\frac{1}{0,1(1,1)^{9}}\right]+100.000=675.902,38 T L$

İlk ödemenin peşin yapıldığı ve taksit ödemeleri her yılın başında yapılacağı için vade 9 yıl olarak dikkate alınmıştır ve kira ödemelerinin (taksitlerin) bugünkü değeri 675.902,38 TL olarak bulunmuştur. Kullanım hakkı hesabının, yükümlülüklerin ve finansman giderlerinin yıllara yaygın tutarları Tablo 1'de sunulmuştur. 
Tablo 1. Kira Ödemlerine Ait İtfa Tablosu

\begin{tabular}{crrrrr}
\hline \multicolumn{1}{c}{$r \begin{array}{r}\text { Toplam } \\
\mathbf{Y 1}\end{array}$} & $\begin{array}{r}\text { Kïra Ö̈demesi } \\
\text { (Taksit) }\end{array}$ & Faiz & Anapara & Kalan Yükümlülük \\
\hline $\mathbf{0}$ & $675.902,38$ & & & 100.000 & $575.902,38$ \\
\hline $\mathbf{1}$ & $575.902,38$ & 100.000 & $57.590,24$ & $42.409,76$ & $533.492,62$ \\
\hline $\mathbf{2}$ & $533.492,62$ & 100.000 & $53.349,26$ & $46.650,74$ & $486.841,88$ \\
\hline $\mathbf{3}$ & $486.841,88$ & 100.000 & $48.684,19$ & $51.315,81$ & $435.526,07$ \\
\hline $\mathbf{4}$ & $435.526,07$ & 100.000 & $43.552,61$ & $56.447,39$ & $379.078,68$ \\
\hline $\mathbf{5}$ & $379.078,68$ & 100.000 & $37.907,87$ & $62.092,13$ & $316.986,54$ \\
\hline $\mathbf{6}$ & $316.986,54$ & 100.000 & $31.698,65$ & $68.301,35$ & $248.685,20$ \\
\hline $\mathbf{7}$ & $248.685,20$ & 100.000 & $24.868,52$ & $75.131,48$ & $173.553,72$ \\
\hline $\mathbf{8}$ & $173.553,72$ & 100.000 & $17.355,37$ & $82.644,63$ & $90.909,09$ \\
\hline $\mathbf{9}$ & $90.909,09$ & 100.000 & $9.090,91$ & $90.909,09$ & 0,00 \\
\hline TOPLAM & & 900.000 & $224.097,62$ & $675.902,38$ & \\
\hline
\end{tabular}

Kiralama işleminin ilk muhasebeleştirilmesi K1 ve K2 numaraları kayıtlarda gösterilmektedir. Kiralama işleminden elde edilen kullanım hakkının parasal değeri 675.902,38 TL ölçülmüş olup, bu bedelin 100.000 TL'si peşin ödenmiş, kalan 575.902,38 TL kiralama yükümlülüğü hesabına alacak kaydedilmiştir. Kiralama işleminin temini için katlanılan harcamalar maliyet bedelleri üzerinden kaydedilmektedir. K2' de yapılan komisyon harcamaları kullanım hakkına borç kaydedilerek, kullanım hakkının amortismana tabi değeri ilk muhasebeleştirme işlemleri neticesinde (675.902,38 TL + 30.000,00 TL) 705.902.38 TL bulunmaktadır.

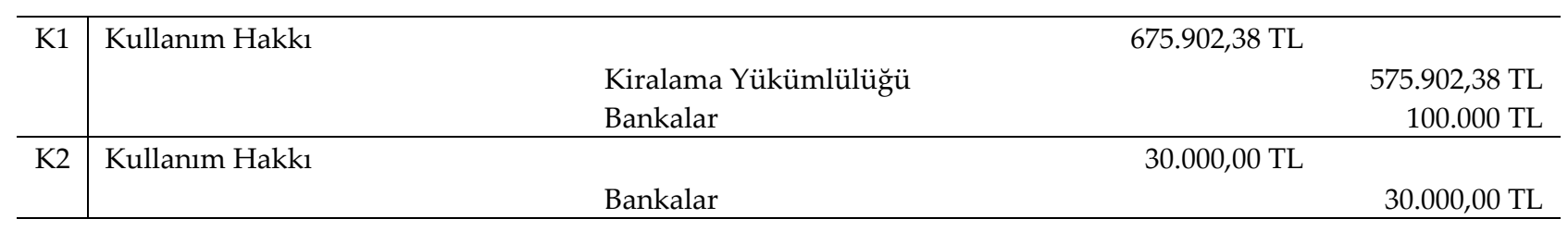

Kiralanan varlık sözleşmeye göre kiracıya devredilecek ise kira süresine göre, devredilmeyecekse kiralanan varlı̆̆ın ekonomik ömrü veya kira süresinden kısa olan süreye göre amortismana tabi tutulacaktır. Örneğimizde, kiralanan varlık kira süresi sonunda kiracıya devredilmeyeceğinden, kira süresi varlığın ekonomik ömründen kısa olduğundan 10 yıl için amortismana tabi tutulacaktır. Bu bahisle yıllık amortisman gideri 70.590,24 TL olacaktır. K3 ve K4 numaralı kayıtlarda sırasıyla amortisman giderinin muhasebeleştirilmesi ve ikinci kira ödemesinin yapılması yer almaktadır.

\begin{tabular}{|c|c|c|c|c|}
\hline \multirow[t]{2}{*}{ K3 } & \multirow[t]{2}{*}{ Genel Yönetim Giderleri } & \multicolumn{3}{|c|}{$70.590,24 \mathrm{TL}$} \\
\hline & & Birikmiş Amortismanlar & & $70.590,24 \mathrm{TL}$ \\
\hline \multirow[t]{3}{*}{ K4 } & Kiralama Yükümlülüğü & & $42.409,76 \mathrm{TL}$ & \\
\hline & Finansman Gideri & & $57.590,24 \mathrm{TL}$ & \\
\hline & & Bankalar & & $100.000,00 \mathrm{TL}$ \\
\hline
\end{tabular}

Ödemeler her yılın başında yapıldı ̆̆ı için, ikinci kira ödemesine ilişkin olarak kiralama yükümlülüğüne ilişkin bir ölçüm değişikliği olmadığı varsayımıyla K4 numaraları kayıt sunulmaktadır. Ancak, unutulmamalıdır ki kiralama işlemlerinin ilk muhasebeleştirilmesi takiben sonraki raporlama dönemlerinde haklar ile yükümlülükler ayrı ayrı ölçüme tabi tutulmalıdır. Kullanım hakkı ve birikmiş amortismanlar, şayet değer düşüklüğüne uğramışsa değer düşüklüğü karşıllğı düşülmüş haliyle finansal tablolarda raporlanacaktır. Diğer standartlarda yeniden değerleme yapılmasına izin veriliyorsa yeniden değerleme de yapılabilecektir. Kira yükümlülügünde ise, emsal kira bedelindeki değişime göre kira bedelleri içerisindeki faiz payı artabilir veya azalabilir.

\section{UFRS 16'NIN KİRACININ FINANSAL TABLOLARI ÜZERINDEKİ BEKLENEN ETKİLERİ}

UMS 17' de faaliyet kiralamaları finansal durum tablosu dışında bırakılmakta ve kira ödemeleri ilgili dönemde doğrudan kaz veya zarar ve diğer kapsamlı gelir tablosunda raporlanmaktaydı. UFRS 16'ya geçişle birlikte faaliyet kiralamalarının da finansal kiralamalarda olduğu gibi hak ve yükümlülükler olarak finansal durum tablosunda raporlanması ve dönemsel olarak amortismanlar ile faiz ödemelerinin sırasıyla faaliyet giderleri ve finansman giderleri uhdesinde kar veya zarar ve diğer kapsamlı gelir tablosu içerisinden raporlanmaya başlaması hiç şüphesiz ki özellikle yüksek hacimde faaliyet kiralaması gerçekleştiren işletmelerin finansal tablolarında değişikliğe yol açabilecektir. Bu değişikliklerin hangi yönde gerçekleşeceğine ilişkin bir 


\section{S. Gökten - G. Arslan Kurnaz 12/2 (2020) 1848-1860}

beklentiler sepeti ortaya koyabilmek doğrultusunda ikinci bölümde verilen ilk muhasebeleştirme örneğinden hareketle Şekil 1 ve Şekil 2'de sırasıyla kiracı açısından kiralama işleminin UMS 17'ye ve UFRS 16'ya göre muhasebeleştirilmesi ve raporlanması görsel olarak sunulmuştur.

UFRS 16'nın uygulanmasıyla birlikte kiracının finansal tablolarında ortaya çıkması beklenen öncül etkiler, Şekil 1 ve 2'den faydalanılarak Tablo 2'de belirtildiği şekilde sıralanabilir. Unutulmamalıdır ki, ifade edilen bu etkiler, finansal tablolarda diğer tüm unsurların sabit kaldığg varsayımına dayanmaktadır ve beklentilerin öncül olarak ifade edilmesinin temel sebebi; beklenen etkilerin UFRS 16 uygulamasının yürürlüğe geçtiği ilk yıllarda fark yaratır şekilde kiracının finansal tablolarına yansıyacağının düşünülmesidir. Ayrıca, sunulan beklentilere ilişkin olarak diğer önemli bir varsayım ise sıfırdan büyük piyasa faiz oranının mevcudiyetidir. Çünkü, r: faiz oranı, BD: kullanım hakkının bugünkü değeri ve ND: kira ödemelerinin nominal değerleri toplamı olmak üzere ' $r>0 \rightarrow B D<N^{\prime}$ ' ve ' $r<0 \rightarrow B D>N D$ 'dir. Diğer bir ifadeyle negatif faiz, paranın zaman değeri esaslı bugünkü değer hesaplamaları itibariyle kullanım hakkının bugünü değerini, kira ödemelerinin nominal tutarları toplamından büyük hale getirecektir ve bu durum beklentilerin tam tersi etkinin oluşmasını sağlayacaktır.

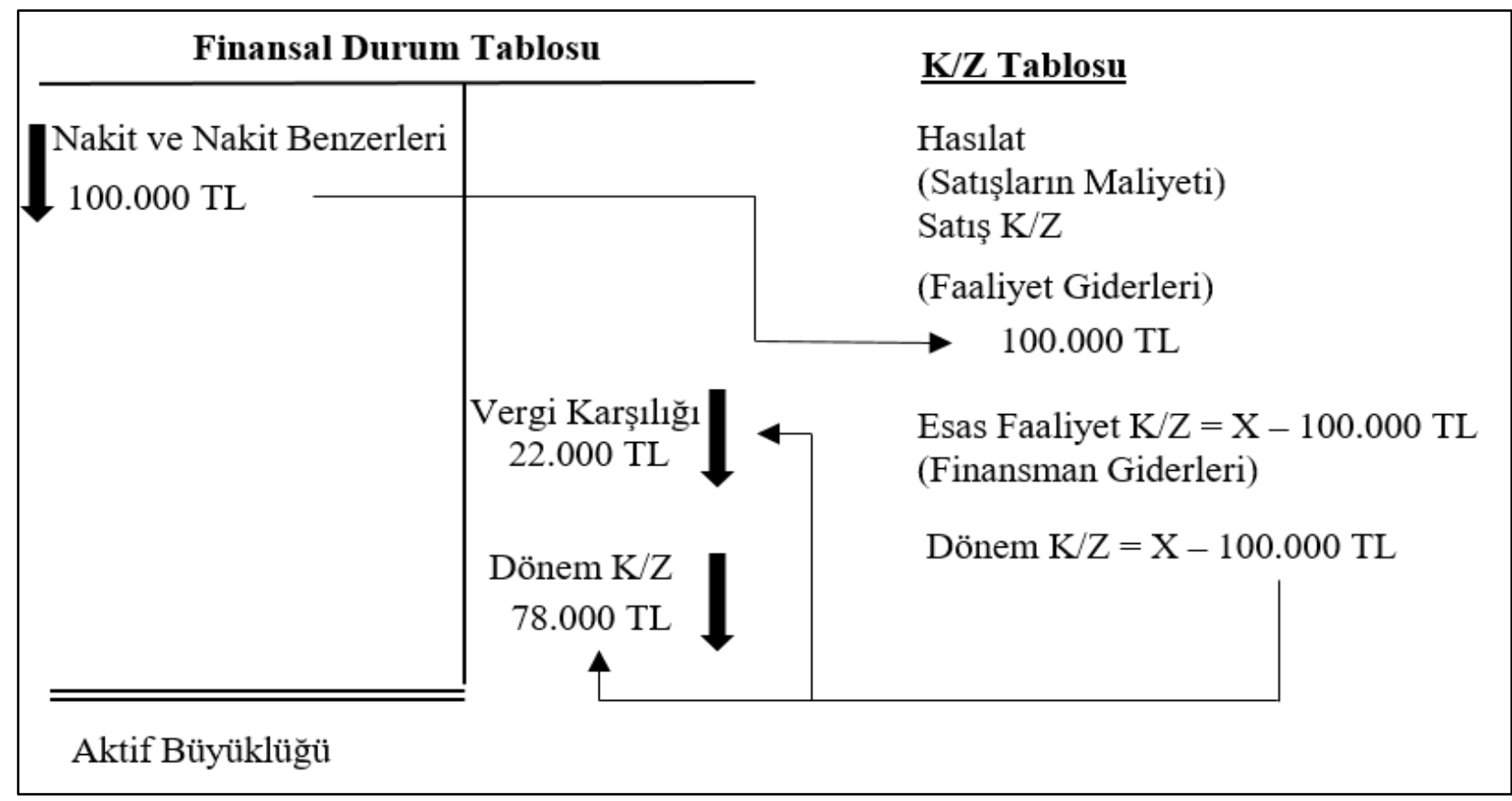

Şekil 1. Kiracı Açısından UMS 17’ye Göre Kiralamanın Muhasebeleştirilmesi ve Raporlanması

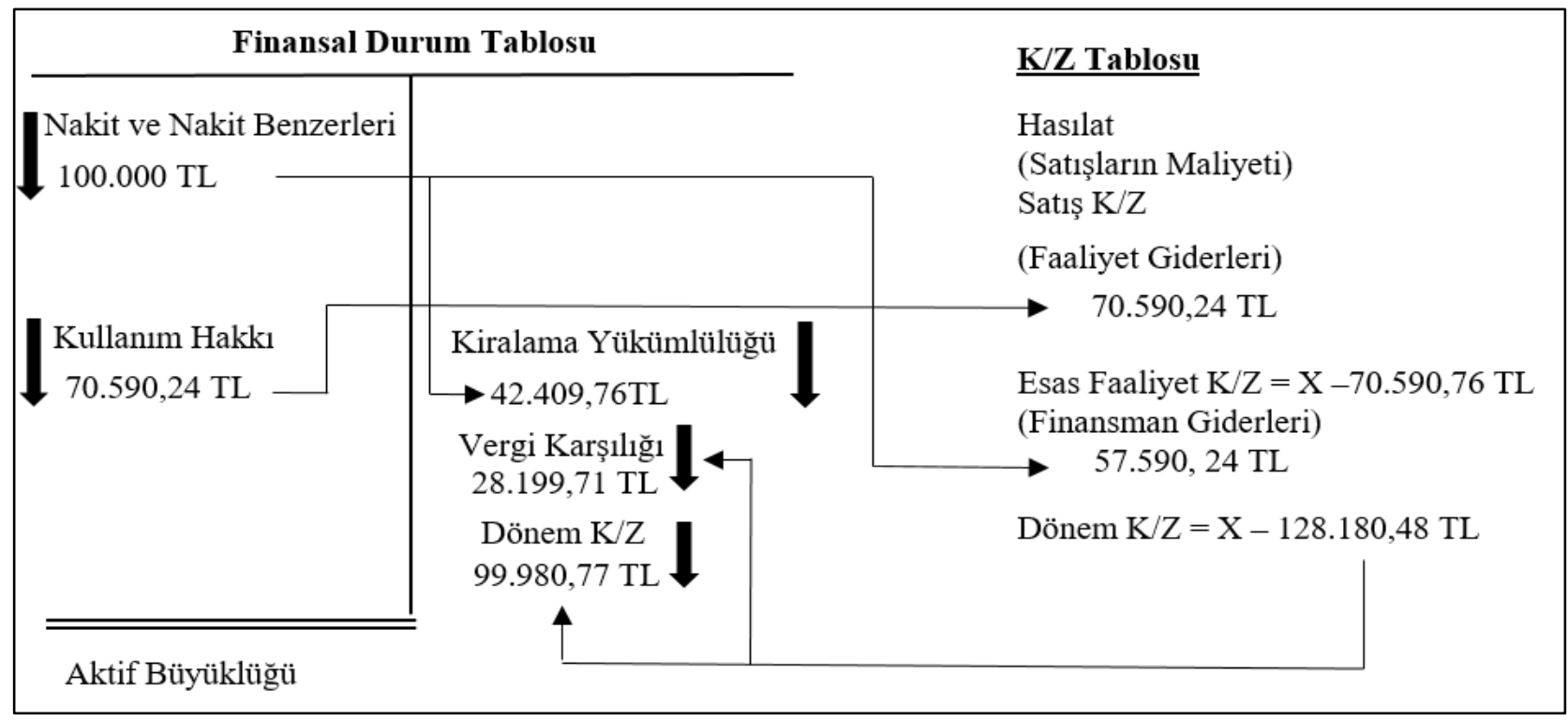

Şekil 2. Kiracı Açısından UFRS 16'ya Göre Kiralamanın Muhasebeleştirilmesi ve Raporlanması 


\section{S. Gökten - G. Arslan Kurnaz 12/2 (2020) 1848-1860}

Tablo 2. UFRS 16'nın Kiracının Finansal Tabloları Üzerindeki Beklenen Öncül Etkileri

\begin{tabular}{|c|c|}
\hline Beklenen Öncül Etki & Karşılaştırma* \\
\hline Finansal durum tablosu büyüklüğünde artış & Aktif büyüklüğünde artış \\
\hline Faaliyet giderlerinde azalış & $70.590,24 \mathrm{TL}<100.000 \mathrm{TL}$ \\
\hline Esas faaliyet karlılığında artış ${ }^{1}$ & $X-70.590,24 \mathrm{TL}>\mathrm{X}-100.000 \mathrm{TL}$ \\
\hline Finansman giderlerinde artış & $57.590,24$ TL finansman gideri \\
\hline Dönem karlılığında azalış & $\mathrm{X}-128.180,48 \mathrm{TL}<\mathrm{X}-100.000 \mathrm{TL}$ \\
\hline Vergi yükünde azalış & $(X-128.180,48 \mathrm{TL}) \times \% 22<(X-100.000 \mathrm{TL}) \times \% 22$ \\
\hline Öz kaynaklarda azalış & $-99.980,77 \mathrm{TL}<-78.000,00 \mathrm{TL}$ \\
\hline \multicolumn{2}{|c|}{$\begin{array}{l}\text { * Karşılaştırma için Şekil } 1 \text { ve 2' de sunulan bilgiler esas alınmıştır. } \\
\text { Beklentilere ilişkin varsayımlar; } \\
\text { 1) Beklenen öncül etki unsurları dışındaki finansal tablo kalemleri sabittir. } \\
\text { 2) Faiz sıfırdan büyüktür. }\end{array}$} \\
\hline
\end{tabular}

UFRS 16'nın finansal tablolar üzerindeki etkilerini finansal tablo kalemlerinin yanı sıra finansal oranlar ve göstergeler üzerinden de değerlendirmek mümkün olacaktır. Kiracının finansal tabloları üzerinde beklenen öncül etkilere ilişkin varsayımlar geçerli olmak üzere verilmiş örnek üzerinden hareket edildiğinde aşağıda belirtilen finansal oranlar ve göstergeler üzerinde yaratması beklenen muhtemel etkiler değerlendirilmiştir.

- Faiz, vergi ve amortisman öncesi kar (FVAÖK): UMS 17'de dönemin kira ödemesi dönemin faaliyet gideri olarak kayıt altına alınırken, UFRS 16 çerçevesinde kullanım hakkının bugünkü değeri üzerinden ayrılan dönemin amortisman tutarı dönemsel faaliyet gideri olarak kayıt edilmektedir. Bu nedenle, UMS 17 uygulamasında dönemsel kira ödemesi FVAÖK hesaplamasına dahil olurken, UFRS 16 çerçevesinde dahil olmamaktadır. Bu nedenle UFRS 16 uygulamasında FVAÖK tutarında artış beklenmektedir (Wong ve Joshi, 2015; Sacarin, 2017; Morales-Díaz, ve Zamora-Ramírez, 2018; Magli ve diğerleri, 2018).

- Varlık devir hızı oranı (Hasılat/Toplam Aktif): Finansal durum tablosu büyüklügündeki (aktifteki) beklenen artış nedeniyle, varlık devir hızında azalış beklenmektedir.

- Finansal kaldıraç oranı (Toplam Yükümlülükler/öz Kaynak $)$ : Yükümlülüklerde ve öz kaynaklarda sırasıyla beklenen artış ve azalış nedeniyle, finansal kaldıraç oranında artış beklenmektedir (Morales-Díaz, ve Zamora-Ramírez, 2018).

- Likidite oranları (ilgili oranın payı²/Kısa Vadeli Yabancı Karbaklar): Kiralama yükümlülügünün kısa vadeli kısmı cari borçları artıracağı için, likidite oranlarının tümünde azalış beklenmektedir.

UFRS 16'nın kiracının finansal oranları ve göstergeleri üzerinde yaratması beklenen öncül etkiler ve bunların değerlendirilmesi Tablo 3'de sunulmaktadır.

Tablo 3. UFRS 16'nın Kiracının Finansal Oranları ve Göstergeleri Üzerindeki Beklenen Öncül Etkileri

\begin{tabular}{|l|l|l|}
\hline Oran, gösterge & Beklenti & Değerlendirme \\
\hline FVAÖK & Artış & Firmaya serbest nakit akışı hesaplamalarında artış yaratacaktır. \\
\hline Varlık devir hızı oranı & Azalış & Varlık etkinliğinin düşük görünmesine (atıl kapasite) yol açacaktır. \\
\hline Finansal kaldıraç oranı & Artış & Uzun vadeli finansal riskliliği artıracaktır. \\
\hline Likidite oranları & Azalış & Kısa vadeli finansal riski artıracaktır. \\
\hline
\end{tabular}

\section{BEKLENEN ETKİLERİN GEÇERLİLİĞİNIN İNCELENMESİ: BULGULAR}

Uluslararası Muhasebe Standartları Kurulu tarafından 2016 Ocak itibariyle yayınlanan UFRS 16 etki analizi raporunda; finansal raporlama sonuçları itibariyle hava yolu sektörünün değişiklikten en fazla etkilenecek sektör olacağı belirtilmiştir (UFRSEA, 2016, s.16-17). Söz konusu etki analizinde, farklı sektörlerden 1022 adet işletmenin finansal tabloları incelenmiştir. İncelenen işlemelerin 482'si Kuzey Amerika, 348'i Avrupa, 140'1 Asya/Pasifik, 29'u Latin Amerika, 23'ü ise Afrika/Orta Doğu bölgelerinde faaliyet göstermektedir. Hava yolunu takiben etki sıralaması perakende, seyahat ve eğlence, taşımacılık, telekomünikasyon, enerji ve medya

\footnotetext{
${ }^{1}$ Sacarin (2017) de çalışmasında, UFRS 16 uygulamasıyla faaliyet karında artış beklentisini ortaya koymuştur.

${ }^{2}$ Cari oran için 'dönen varlıklar', likidite (asit test) oranı için 'dönen varlıklar - stoklar' ve nakit oranı için 'nakit ve nakit benzerleri' kullanılmaktadır.
} 


\section{S. Gökten - G. Arslan Kurnaz 12/2 (2020) 1848-1860}

olarak belirtilmektedir. Hiç şüphesiz ki, söz konusu etki sıralaması aynı zamanda ilgili sektörlerin faaliyet kiralaması hacimlerinin de büyüklük sıralamasını ortaya koymaktadır.

Bu çalışmada Uluslararası Muhasebe Standartları Kurulu tarafından yayınlanan UFRS 16 etki analizi raporu dikkate alınarak, UFRS 16'nın kiracının finansal tabloları üzerinde yaratacağı etkiler seçilmiş hava yolu işletmeleri üzerinden analiz edilmiştir. Bu nedenle çalışmamızda Türk Hava Yolları (THY), Pegasus Hava Yolları (PHY), Lutfhansa Hava Yolları (LHY) ve İskandinav Hava Yolları (IHHY) olmak üzere dört hava yolu işletmesinin UFRS 16'ya göre hazırlanan finansal tabloları incelenmiştir. Çalışmada sunulan beklenen öncül etkilerin geçerliliği THY'nin, PHY'nin, LHY'nin 31.12.2019 tarihli finansal raporları, İHY'nin ise 31.01.2020 tarihli finansal raporu incelenerek değerlendirilmiştir. İHY özel hesap dönemi (01.11.2018-31.10.2019) uygulamaktadır ve UFRS 16'ya ilk kez 1.11.2019 tarihinde geçmiştir.

UFRS 16 C5 paragrafında kiracılara yeni uygulamaya geçiş için iki seçenek sunulmaktadır. Birinci seçenek çerçevesinde kiracıların 8 numaralı 'Muhasebe Politikaları, Muhasebe Tahminlerinde Değişiklikler ve Hatalar' isimli Uluslararası Muhasebe Standardı uyarınca önceki dönemler için karşılaştırmalı olarak geriye dönük uygulama yapabilecekleri belirtilmektedir. İkinci seçeneğe göreyse, UFRS 16'nın ilk kez uygulandığ finansal tablolarda kümülatif etki dikkate alınarak geriye dönük olarak uygulanabilecektir. İkinci seçeneğin tercih edilmesi durumunda karşılaştırmalı bilgiler tekrar düzenlenmeyecek, kümülatif etki dağıtılmamış karların açılış bakiyesinde veya tercih edilecek öz kaynak hesaplarında düzeltme işlemi olarak finansal tablolara yansıtılacaktır. Ayrıca UFRS 16'nın C8 paragrafında belirtildiği şekliyle, kiracılar daha önce faaliyet kiralaması olarak sınıflandırdıkları kiralama işlemleri ile ilgili olarak, aşağıda yer alan kolaylaştırıcı işlemleri uygulayabileceklerdir (TFRS 16, 2018, s.29).

- Özellikleri benzeyen kiralamaların tamamına aynı iskonto oranı uygulanabilir.

- Kiracı değer düşüklüğünü dikkate almadan, 27 numaralı 'Karşılıklar, Koşullu Borçlar ve Koşullu Varlıklar' isimli Uluslararası Muhasebe Standardını uygulayarak, kiralamanın ekonomik olarak dezavantajlı olup olmadığını ilk uygulama tarihinden önce değerlendirebilir.

- Ilk uygulama tarihinden itibaren 12 ay içerisinde süresi bitecek olan kiralamalara UFRS 16'y1 uygulamayabilir. Böyle bir durumda bu kiralamaları kısa vadeli kiralama olarak muhasebeleştirebilir veya açıklamalarda bu kiralamalara ilişkin maliyeti kısa vadeli kiralama giderlerine ekleyebilir.

- Kullanım hakkının ölçümünde, başlangıçta katlanılan doğrudan maliyetleri eklemeyebilir.

- Kira süresini belirlerken sözleşmede kira süresinin uzatılması veya sonlandırılması opsiyonları varsa geçmiş dönemden sonra öğrenilmiş bilgileri kullanabilir.

Seçilen havayolu işletmelerinin tamamı UFRS 16'ya geçişte kolaylaştırılmış geçiş hükümlerinden faydalanmıştır.

\subsection{Türk Hava Yolları'na Ait Bulgular}

THY'nin 31.12.2019 tarihli finansal durum tablosunda bir önceki yıla göre duran varlıklar toplamı 33.162 milyon TL artmıştır. İşletme kolaylaştırılmış yaklaşımı tercih ettiğinden 1.1.2019 tarihli açılış bakiyelerini düzeltmiştir. 1.1.2019 tarihli finansal durum tablosunda UFRS 16'ya ilk geçiş nedeniyle kullanım hakkı 8.582 milyon TL artırmıştır. Bu bağlamda UFRS 16 nedeniyle duran varlıklarda ve aktif toplamında sırasıyla \%10 ve \%8 düzeyinde artış yaşanmıştır. Bu etki yükümlülüklerin ise \%11 düzeyinde artışına sebebiyet vermiştir. UFRS 16 nedeniyle öz kaynaklarda 40 milyon TL düzeyinde azalma meydana gelmiştir.

THY 1.1.2019-31.12.2019 döneminde 1.241 milyon TL hacminde yeni faaliyet kiralaması yapmıştır. 31.12.2019 tarihli finansal durum tablosunda, bir önceki yıla göre duran varlıklarda meydana gelen artışın $\% 9^{\prime} \mathrm{u}$, finansal durum tablosu büyüklüğünde meydana gelen artı̧ın ise \%7'si UFRS 16 kaynaklıdır. 31.12.2019 tarihli finansal durum tablosunda, bir önceki yıla göre UFRS 16 kaynaklı yükümlülüklerde $\% 12$ artış, öz kaynaklarda \%3 azalış meydana gelmiştir.

THY'nin kar veya zarar ve diğer kapsamlı gelir tablosu incelendiğinde, THY'nin FVAÖK tutarının 11.446 milyon TL'den 13.666 milyon TL'ye yükseldiği görülmüştür. İşletmenin 2018 yılı denetim raporundan 12 aydan kısa süreli faaliyet tipi uçak kiralamalarının 1.773 milyon TL, faaliyet tipi diğer kiralamalarının ise 22 milyon TL olduğu anlaşılmaktadır. İşletme 2019 hesap döneminde kiralama işlemleri ile ilgili olarak 1.788 milyon TL amortisman ve 323 milyon TL faiz giderini finansal tablolara almıştır. Niteliklerine göre gider 


\section{S. Gökten - G. Arslan Kurnaz 12/2 (2020) 1848-1860}

sinıflandırmasında amortisman ve itfa payı giderlerinin 1.1.2018-31.12.2018 döneminde 5.254 milyon TL, 1.1.2019-31.12.2019 döneminde ise 8.624 milyon TL olduğu denetim raporunda yer almaktadır.

THY'nin 31.12.2019 tarihli finansal tabloları ve bağımsız denetim raporu üzerinden yapılan inceleme neticesinde, UFRS 16'ya geçişin gerçekleşen etkileri ve bunların beklentilerle ne ölçüde tutarlı olduğu Tablo 4'de sunulmaktadır. Kiracının finansal tablolarındaki etkiye ilişkin olarak ortaya konulan öncül beklentilerin tamamı THY açısından gerçekleşmiştir.

Tablo 4. UFRS 16'ya Geçişin THY'nin Finansal Tabloları Üzerindeki Etkileri

\begin{tabular}{|c|c|c|}
\hline Beklenen Öncül Etki & Bulgu $^{*}$ & Karşılaştırma \\
\hline Finansal durum tablosu büyüklüğünde artış* & $\sqrt{ }$ & 8.035 milyon TL artış \\
\hline Faaliyet giderlerinde azalış ${ }^{* *}$ & $\sqrt{ }$ & 1.788 milyon $\mathrm{TL}<1.795$ milyon $\mathrm{TL}$ \\
\hline Esas faaliyet karlılığında artış & $\sqrt{ }$ & $\mathrm{X}-1.788$ milyon $\mathrm{TL}>\mathrm{X}-1.795$ milyon $\mathrm{TL}$ \\
\hline Finansman giderlerinde artış & $\sqrt{ }$ & 323 milyon TL finansman gideri \\
\hline Dönem karlılı̆̆ında azalış & $\sqrt{ }$ & $\mathrm{X}-2.111$ milyon $\mathrm{TL}<\mathrm{X}-1.795$ milyon $\mathrm{TL}$ \\
\hline Vergi yükünde azalış*** & $\sqrt{ }$ & $(X-2.111$ milyon $\mathrm{TL}) \times 22 \%<(\mathrm{X}-1.795$ milyon $\mathrm{TL}) \times 22 \%$ \\
\hline Öz kaynaklarda azalış & $\sqrt{ }$ & $-1.646,58$ milyon $\mathrm{TL}<-1.400,10$ milyon TL \\
\hline \multicolumn{3}{|c|}{$\begin{array}{l}\text { * Kullanım hakkı varlıklarının net defter değerleri esas alınmıştır. } \\
\text { **Faaliyet kiralamalarına ilişkin giderler } 31.12 .2018 \text { tarihli Kar/Zarar Tablosundan alınmış olup, enflasyon etkisi ihmal edilmiş olup } \\
\text { tamamının UFRS } 16 \text { kapsamında kullanım hakkı olarak finansal durum tablosuna aktarıldığı varsayılmıştır. } \\
\text { *** Vergi yükünün \% } 22 \text { olduğu varsayılmıştır. } \\
\text { \# }\end{array}$} \\
\hline
\end{tabular}

UFRS 16'ya geçişin kiracının finansal oranları ve göstergeleri üzerinde yaratması beklenen öncül etkiler ile gerçekleşen etkilerin karşılaştırılması Tablo 5'te sunulmaktadır. Kiracının finansal oranları ve göstergeleri üzerindeki etkiye ilişkin olarak ortaya konulan öncül beklentilerin tamamının karşılandığı ifade edebilir. Sadece beklenen azalışa karşın nakit oranda artış olduğu tespit edilmiştir. Bunun nedeni, THY'nin banka mevduatlarında yaşanan \%43 düzeyindeki artıştır.

Tablo 5. UFRS 16'ya Geçişin THY'nin Finansal Oranları ve Göstergeleri Üzerindeki Etkileri

\begin{tabular}{|l|r|r|r|r|c|}
\hline Oran, gösterge & Beklenti & 2019 Hesap Dönemi & 2018 Hesap Dönemi & Değişim & Bulgu $^{\#}$ \\
\hline FVAÖK (milyon TL) & Artış & 13.666 & 11.446 & 2.220 & $\sqrt{ }$ \\
\hline Varlık devir hızı oranı & Azalış & 0,51 & 0,58 & $(0,07)$ & $\sqrt{ }$ \\
\hline Finansal kaldıraç oranı & Artış & 2,60 & 2,49 & 0,11 & $\sqrt{ }$ \\
\hline Likidite oranları & Azalış & 0,80 & 0,87 & $(0,07)$ & $\sqrt{ }$ \\
\hline Cari oran & Azalış & 0,75 & 0,83 & $(0,08)$ & $\sqrt{ }$ \\
\hline Asit test oranı & Azalış & 0,35 & 0,32 & 0,03 & $\times$ \\
\hline Nakit oran & & & &
\end{tabular}

\# $\sqrt{ }$ işareti beklenen etkinin gerçekleştiğini, $\times$ işareti gerçekleşmediğini ifade etmektedir.

\subsection{Pegasus Hava Yolları'na Ait Bulgular}

PHY'nin 31.12.2019 tarihli finansal durum tablosunda bir önceki yıla göre duran varlıklar toplamı 5.617 milyon TL artmıştır. İşletme kolaylaştırılmış yaklaşımı tercih ettiğinden 1.1.2019 tarihli açılış bakiyelerini düzeltmiştir. 1.1.2019 da finansal durum tablosunda UFRS 16'ya ilk geçiş nedeniyle kullanım hakkı 2.469 milyon TL artırmıştır. Bu bağlamda UFRS 16 duran varlıklarda \%27, aktif büyüklügünde ise $\% 18$ oranında artışa neden olmuştur. Bu etki yükümlülüklerin ise \%26 düzeyinde artışına sebebiyet vermiştir. UFRS 16 nedeniyle öz kaynaklarda 330 milyon TL düzeyinde azalma meydana gelmiştir.

1.1.2019 itibariyle UFRS 16 uyarınca muhasebeleştirilen kullanım haklarının net defter değeri 9.307 milyon TL iken 31.12.2019 tarihinde kullanım haklarının net defter değeri 11.906 milyon TL'dir. İşletmenin 31.12.2019 tarihli finansal durum tablosunda, bir önceki yıla göre duran varlıklarda meydana gelen artışın \%28'i, finansal durum tablosu büyüklüğünde meydana gelen artışın ise \%19'u UFRS 16 kaynaklıdır. Ayrıca, 31.12.2019 tarihli finansal durum tablosunda bir önceki yıla göre kiralama yükümlülüklerinde \%29 artış, öz kaynaklarda ise \%16 azalış meydana gelmiştir. İşletmenin 31.12.2019 tarihli finansal durum tablosunda uzun vadeli faaliyet kiralama borçlarının kısa vadeli kısımları 635 milyon TL, uzun vadeli faaliyet kiralama borçları 1.614 milyon TL olarak raporlanmıştır. 


\section{S. Gökten - G. Arslan Kurnaz 12/2 (2020) 1848-1860}

1.2019-31.12.2019 dönemi kar/zarar tablosunda, UFRS 16'nın satışların maliyetine etkisinin 295 milyon TL, finansman giderlerine etkisinin ise 247 milyon TL olduğu bağımsız denetim raporunda belirtilmektedir. Ayrıca amortisman giderleri 2018 yılında 538 milyon TL iken 2019 yılında 1.547 milyon olarak raporlanmaktadır. 8.270 milyon TL'nin UFRS 16 kapsamında kullanım hakkı varlıklarına transfer edildiği bilgisi yer almaktadır. 2019 yılı sonu itibariyle faaliyet kiralamalarına ilişkin yükümlülüklerin 2.249 milyon TL olduğu anlaşılmakta ancak faaliyet kiralamalar dışındaki amortisman giderlerindeki artışın kaynă̆ 1 anlaşılamamaktadır.

PHY'nin 31.12.2019 tarihli finansal tabloları ve bağımsız denetim raporu üzerinden yapılan inceleme neticesinde, UFRS 16'ya geçişin gerçekleşen etkileri ve bunların beklentilerle ne ölçüde tutarlı olduğu Tablo 6'da sunulmaktadır. Kiracının finansal tablolarındaki etkiye ilişkin olarak ortaya konulan öncül beklentiler dönem karlılığı, vergi yükü ve öz kaynak değişimi haricinde gerçekleşmiştir. Beklentilerin tersi yönündeki gerçekleşmelerin nedeni faaliyet kiralamalarından amortisman giderinin düşük raporlanmış olmasıdır. Toplam amortisman gider artışı içerisinde faaliyet kiralamalarından amortisman tutarının neden küçük bir paya sahip olduğuna ilişkin bir açıklamaya ise bağımsız denetim raporundan ulaşılamamıştır.

Tablo 6. UFRS 16'ya Geçişin PHY'nin Finansal Tabloları Üzerindeki Etkileri

\begin{tabular}{|c|c|c|}
\hline Beklenen Öncül Etki & Bulgu ${ }^{\#}$ & Karşılaştırma \\
\hline Finansal durum tablosu büyüklüğünde artış* & $\sqrt{ }$ & 2.599 milyon TL artış \\
\hline Faaliyet giderlerinde azalış ** & $\sqrt{ }$ & 295 milyon TL < 694 milyon TL \\
\hline Esas faaliyet karlılığında artış & $\sqrt{ }$ & X - 295 milyon TL > X - 694 milyon TL \\
\hline Finansman giderlerinde artış & $\sqrt{ }$ & 247 milyon TL finansman gideri \\
\hline Dönem karlılığında azalış & $x$ & X - 542 milyon TL > X - 694 milyon TL \\
\hline Vergi yükünde azalış*** & $x$ & $(X-542$ milyon TL $) \times \% 22>(X-694$ milyon $T L) \times \% 22$ \\
\hline Öz kaynaklarda azalış & $x$ & $-422,76$ milyon TL > -541,32 milyon TL \\
\hline \multicolumn{3}{|c|}{$\begin{array}{l}\text { * Kullanım hakkı varlıklarının net defter değerleri esas alınmıştır. } \\
\text { **Faaliyet kiralamalarına ilişkin giderler } 31.12 .2018 \text { tarihli Kar/Zarar Tablosundan alınmış olup, enflasyon etkisi ihmal edilmiş olup, } \\
\text { tamamının UFRS } 16 \text { kapsamında kullanım hakkı olarak finansal durum tablosuna aktarıldığı varsayılmıştır. } \\
\text { *** Vergi yükünün \% } 22 \text { olduğu varsayılmıştır. } \\
\# \sqrt{ } \text { işareti beklenen etkinin gerçekleştiğini, } \times \text { işareti gerçekleşmediğini ifade etmektedir. }\end{array}$} \\
\hline
\end{tabular}

UFRS 16'ya geçişin kiracının finansal oranları ve göstergeleri üzerinde yaratması beklenen öncül etkiler ile gerçekleşen etkilerin karşılaştırılması Tablo 7'de sunulmaktadır. Kiracının finansal oranları ve göstergeleri üzerindeki etkiye ilişkin olarak ortaya konulan öncül beklentilerin likidite oranları haricinde karşılandığı görülmektedir. İşletmenin nakit ve nakit benzerleri 31.12.2018 finansal durum tablosunda 2.741 milyon TL iken 31.12.2019 finansal durum tablosunda 4.187 milyon TL düzeyinde raporlanmıştır. Nakit ve nakit benzerlerinin bir önceki yıla göre \% 53 oranında artış göstermesi, likidite oranlarının artmasında temel rol oynamıştır. Duran varlıkları dönen varlıklara dönüştüren amortisman tutarındaki artış, nakit ve nakit benzerlerindeki artışta rol oynamıştır.

Tablo 7. UFRS 16'ya Geçişin PHY'nin Finansal Oranları ve Göstergeleri Üzerindeki Etkileri

\begin{tabular}{|c|c|c|c|c|c|}
\hline Oran, gösterge & Beklenti & 2019 Hesap Dönemi & 2018 Hesap Dönemi & Değişim & Bulgu $^{\#}$ \\
\hline FVAÖK (milyon TL) & Artış & 3.609 & 1.330 & 2.279 & $\sqrt{ }$ \\
\hline Varlık devir hızı oranı & Azalış & 0,52 & 0,61 & $(0,08)$ & $\sqrt{ }$ \\
\hline $\begin{array}{l}\text { Finansal kaldıraç } \\
\text { oranı }\end{array}$ & Artış & 2,94 & 2,68 & 0,26 & $\sqrt{ }$ \\
\hline \multicolumn{6}{|l|}{ Likidite oranları } \\
\hline Cari oran & Azalış & 1,28 & 1,24 & 0,04 & $x$ \\
\hline Asit test oranı & Azalış & 1,26 & 1,23 & 0,04 & $x$ \\
\hline Nakit oran & Azalış & 0,88 & 0,77 & 0,11 & $\times$ \\
\hline \multicolumn{6}{|c|}{$\begin{array}{l}\text { * Kullanım hakkı varlıklarının net defter değerleri esas alınmıştır. } \\
\text { **Faaliyet kiralamalarına ilişkin giderler 31.12.2018 tarihli Kar/Zarar Tablosundan alınmış olup, enflasyon etkisi ihmal edilmiş olup, } \\
\text { tamamının UFRS } 16 \text { kapsamında kullanım hakkı olarak finansal durum tablosuna aktarıldığı varsayılmıştır. } \\
\text { *** Vergi yükünün \% } 22 \text { olduğu varsayılmıştır. } \\
\text { \# } \text { V işareti beklenen etkinin gerçekleştiğini, } \times \text { işareti gerçekleşmediğini ifade etmektedir. }\end{array}$} \\
\hline
\end{tabular}




\section{S. Gökten - G. Arslan Kurnaz 12/2 (2020) 1848-1860}

\subsection{Lufthansa Hava Yolları'na Ait Bulgular}

LHY'nin 1.1.2019 tarihli finansal durum tablosunda UFRS 16 ilk uygulama nedeniyle kullanım hakları 1.951 milyon Euro artarak duran varlıklarda \%7, aktif büyüklügünde ise \%5 artışa neden olmuştur. Faaliyet kiralamalarına ilişkin yükümlülükler toplamı ise 1.958 milyon Euro olmak üzere \% 6 oranında artış göstermiştir. Öz kaynaklarda 7 milyon Euro azalma meydana gelmiştir. 31.12.2019 tarihli finansal durum tablosunda, bir önceki yıla göre duran varlıklarda meydana gelen artışı $\% 9^{\prime} \mathbf{u}$, finansal durum tablosu büyüklüğünde meydana gelen artışın ise \%6'sı UFRS 16 kaynaklıdır. Bir önceki yıla göre kiralama yükümlülüklerinde $\% 8$ artış, öz kaynaklarda ise $\% 0,24$ azalış meydana gelmiştir.

LHY'nin kar veya zarar ve diğer kapsamlı gelir tablosu incelendiğinde, UFRS 16 uyarınca 2019 hesap döneminde kiralama işlemleri ile ilgili olarak 401 milyon Euro amortisman ve 53 milyon Euro faiz giderinin finansal tablolara yansıtıldığı görülmektedir. Niteliklerine göre gider sınıflandırmasında amortisman ve itfa payı giderleri 1.1.2018-31.12.2018 döneminde 2.205 milyon Euro, 1.1.2019-31.12.2019 döneminde ise 2.776 milyon Euro raporlanmıştır. İşletmenin 31.12.2018 hesap döneminde faaliyet kiralamalarına ilişkin kira ödemelerinin 528 milyon Euro'dur.

LHY'nin 31.12.2019 tarihli finansal tabloları ve bağımsız denetim raporu üzerinden yapılan inceleme neticesinde, UFRS 16'ya geçişin gerçekleşen etkileri ve bunların beklentilerle ne ölçüde tutarlı olduğu Tablo 8 'de sunulmaktadır. Kiracının finansal tablolarındaki etkiye ilişkin olarak ortaya konulan öncül beklentiler dönem karlılığı, vergi yükü ve öz kaynak değişimi haricinde karşılanmıştır. Beklentilerin tersi yönündeki gerçekleşmelerin nedeninin düşük borçlanma maliyetleri olduğu düşünülmektedir.

Tablo 8. UFRS 16'ya Geçişin LHY'nin Finansal Tabloları Üzerindeki Etkileri

\begin{tabular}{|c|c|c|}
\hline Beklenen Öncül Etki & Bulgu $^{\#}$ & Karşılaştırma \\
\hline Finansal durum tablosu büyüklüğünde artış* & $\sqrt{ }$ & 2.363 milyon Euro artış \\
\hline Faaliyet giderlerinde azalış ** & $\sqrt{ }$ & 401 milyon Euro < 528 milyon Euro \\
\hline Esas faaliyet karlılığında artış & $\sqrt{ }$ & X - 401 milyon Euro $>$ X - 528 milyon Euro \\
\hline Finansman giderlerinde artış & $\sqrt{ }$ & 53 milyon Euro finansman gideri \\
\hline Dönem karlılığında azalış & $\times$ & X - 454 milyon Euro > X - 528 milyon TL \\
\hline Vergi yükünde azalış ${ }^{* * *}$ & $\times$ & $(X-454$ milyon Euro $) \times \% 22>(X-528$ milyon Euro $) \times \% 22$ \\
\hline Öz kaynaklarda azalış & $\times$ & $-354,12$ milyon Euro > -411,84 milyon Euro \\
\hline \multicolumn{3}{|c|}{$\begin{array}{l}\text { * Kullanım hakkı varlıklarının net defter değerleri esas alınmıştır. } \\
\text { **Faaliyet kiralamalarına ilişkin giderler 31.12.2018 tarihli Kar/Zarar Tablosundan alınmış olup, enflasyon etkisi ihmal edilmiş olup } \\
\text { tamamının UFRS } 16 \text { kapsamında kullanım hakkı olarak finansal durum tablosuna aktarıldığı varsayılmıştır. } \\
\text { *** Vergi yükünün \% } 22 \text { olduğu varsayılmışıtı. }\end{array}$} \\
\hline
\end{tabular}

UFRS 16'ya geçişin kiracının finansal oranları ve göstergeleri üzerinde yaratması beklenen öncül etkiler ile gerçekleşen etkilerin karşılaştırılması Tablo 9'da sunulmaktadır. Kiracının finansal oranları ve göstergeleri üzerindeki etkiye ilişkin olarak ortaya konulan öncül beklentilerin kısmen karşılandığı görülmektedir. Faiz, vergi ve amortisman öncesi karın beklenenin aksine azalmasının nedeni bir önceki yıla göre satışların maliyetinde $\% 8$, personel giderlerinde $\% 3,5$ oranında artış olmasıdır. Cari oran ve asit test oranının bir önceki yıla göre artmasının nedeni ise borçların yapılandırılması ve gelir vergisi yükümlülügünün düşmesi gibi nedenlerle kısa vadeli yükümlülüklerin azalmasıdır.

Tablo 9. UFRS 16'ya Geçişin LHY'nin Finansal Oranları ve Göstergeleri Üzerindeki Etkileri

\begin{tabular}{|l|r|r|r|r|c|}
\hline Oran, gösterge & Beklenti & 2019 Hesap Dönemi & 2018 Hesap Dönemi & Değişim & Bulgu $^{\#}$ \\
\hline FVAÖK (milyon Euro) & Artış & 4.465 & 5.005 & $(540)$ & $\times$ \\
\hline Varlık devir hızı oranı & Azalış & 0,85 & 0,93 & $(0,08)$ & $\sqrt{ }$ \\
\hline Finansal kaldıraç oranı & Artış & 3,16 & 2,99 & 0,17 & $\sqrt{ }$ \\
\hline Likidite oranları & \multicolumn{7}{|l|}{} \\
\hline Cari oran & Azalış & 0,71 & 0,66 & 0,05 & $\times$ \\
\hline Asit test oranı & Azalış & 0,64 & 0,60 & 0,05 & $\times$ \\
\hline Nakit oran & Azalış & 0,09 & 0,09 & $(0,004)$ & $\sqrt{ }$ \\
\hline
\end{tabular}

$\# \sqrt{ }$ işareti beklenen etkinin gerçekleştiğini, $\times$ işareti gerçekleşmediğini ifade etmektedir. 


\section{S. Gökten - G. Arslan Kurnaz 12/2 (2020) 1848-1860}

\section{4.İskandinav Hava Yolları'na Ait Bulgular}

İHY 1.11.2018-31.10.2019 özel hesap dönemi için finansal tablolarını açıklamış ve işletmenin yıllık raporu 1.11.2018-31.10.2019 dönemini kapsayacak şekilde hazırlanmıştır. Kolaylaştırılmış yaklaşım tercih edildiğinden 1.11.2019 tarihli açllış bakiyelerini düzeltmiştir. İHY'de 31.1.2020 tarihli finansal durum tablosu ile 1.11.2019-31.1.2020 tarihli kar/zarar tablosu esas alınmak suretiyle analiz yapılmıştır. UFRS 16 ilk uygulaması ile birlikte 1.11.2019 tarihli finansal durum tablosunda kullanım hakları 16.680 milyon SEK artmış, bu durum duran varlıklarda \%75, aktif büyüklügünde ise \%49 artış yaşanmıştır. 1.11.2019 tarihli finansal durum tablosunda faaliyet kiralamalarına ilişkin yükümlülükler toplamı da aynı tutarda artmıştır. Artış oranı \%58'dir. 31.1.2020 tarihli finansal durum tablosunda, bir önceki yıla göre duran varlıklarda meydana gelen artışın \%77'si, finansal durum tablosu büyüklügünde meydana gelen artışın ise \%53'ü UFRS 16 kaynaklıdır. 31.1.2020 tarihli finansal durum tablosunda, bir önceki yıla göre kiralama yükümlülüklerinde \% 61 artış, öz kaynaklarda \%3 azalış meydana gelmiştir.

İHY'nin kar veya zarar ve diğer kapsamlı gelir tablosu incelendiğinde, 1.11.2019-31.1.2020 hesap döneminde kiralama işlemleri ile ilgili olarak 869 milyon SEK amortisman ve 199 milyon SEK faiz giderinin raporlandığı, diğer giderlerin 938 milyon SEK azaldığı görülmektedir.

İHY'nin 31.01.2020 tarihli finansal tabloları ve bağımsız denetim raporu üzerinden yapılan inceleme neticesinde, UFRS 16'ya geçişin gerçekleşen etkileri ve bunların beklentilerle ne ölçüde tutarlı olduğu Tablo 10 'da sunulmaktadır. Kiracının finansal tablolarındaki etkiye ilişkin olarak ortaya konulan öncül beklentilerin tamamı İHY açısından gerçekleşmiştir.

Tablo 10. UFRS 16'ya Geçişin İHY'nin Finansal Tabloları Üzerindeki Etkileri

\begin{tabular}{|c|c|c|}
\hline Beklenen Öncül Etki & Bulgu ${ }^{\#}$ & Karşılaştırma \\
\hline Finansal durum tablosu büyüklüğünde artış* & $\sqrt{ }$ & 17.382 milyon SEK artış \\
\hline Faaliyet giderlerinde azalış ${ }^{* *}$ & $\sqrt{ }$ & 869 milyon SEK < 938 milyon SEK \\
\hline Esas faaliyet karlılığında artış & $\sqrt{ }$ & $X-869$ milyon SEK > X - 528 milyon SEK \\
\hline Finansman giderlerinde artış & $\sqrt{ }$ & 199 milyon SEK finansman gideri \\
\hline Dönem karlılı̆̆ında azalış & $\sqrt{ }$ & $\mathrm{X}-1,068$ milyon SEK $<\mathrm{X}-938$ milyon SEK \\
\hline Vergi yükünde azalış*** & $\sqrt{ }$ & $(X-1.068$ milyon SEK $) \times \% 22<(X-938$ milyon SEK $) \times \% 22$ \\
\hline Öz kaynaklarda azalış & $\sqrt{ }$ & -833,04 milyon SEK <-731,64 milyon SEK \\
\hline
\end{tabular}

UFRS 16'ya geçişin kiracının finansal oranları ve göstergeleri üzerinde yaratması beklenen öncül etkiler ile gerçekleşen etkilerin karşılaştırılması Tablo 11'de sunulmaktadır. Kiracının finansal oranları ve göstergeleri üzerindeki etkiye ilişkin olarak ortaya konulan öncül beklentilerin tamamı karşılanmıştır.

Tablo 11. UFRS 16'ya Geçişin İHY'nin Finansal Oranları ve Göstergeleri Üzerindeki Etkileri

\begin{tabular}{|l|r|r|r|r|c|}
\hline Oran, gösterge & Beklenti & 2019 Hesap Dönemi & 2018 Hesap Dönemi & Değişim & Bulgu $^{\sharp}$ \\
\hline FVAÖK (milyon SEK) & Artış & 602 & $(42)$ & 644 & $\sqrt{ }$ \\
\hline Varlık devir hızı oranı & Azalış & 0,19 & 0,29 & $(0,10)$ & $\sqrt{ }$ \\
\hline Finansal kaldıraç oranı & Artış & 10,79 & 5,95 & 4,84 & $\sqrt{ }$ \\
\hline Likidite oranları & Azalış & 0,52 & 0,68 & $(0,16)$ & $\sqrt{ }$ \\
\hline Cari oran & Azalış & 0,50 & 0,74 & $(0,16)$ & $\sqrt{ }$ \\
\hline Asit test oranı & Azalış & 0,35 & 0,47 & $(0,12)$ & $\sqrt{ }$ \\
\hline \multicolumn{2}{|l|}{ Nakit oran } & &
\end{tabular}

\# $\sqrt{ }$ işareti beklenen etkinin gerçekleştiğini, $\times$ işareti gerçekleşmediğini ifade etmektedir.

\section{SONUÇ VE TARTIŞMA}

Çalışmada, UFRS 16'ya geçişin kiracının finansal tabloları, oranları ve göstergeleri üzerinde yaratacağ etkilerin değerlendirilmesi amacıyla 17 adet beklenen öncül etki tanımlanmıştır. Türk Hava Yolları'nın, Pegasus Hava Yolları'nın, Lutfhansa Hava Yolları'nın ve İskandinav Hava Yolları'nın ilk kez UFRS 16'ya uygun olarak yayınlanan finansal raporları vasıtasıyla elde edilen bulgular, beklenen etkilerin neredeyse 


\section{S. Gökten - G. Arslan Kurnaz 12/2 (2020) 1848-1860}

tamamının gerçekleştiğini ortaya koymaktadır. Beklentilerle ters yöndeki gerçekleşmeler, esas itibariyle UFRS 16 kaynaklı değildir.

Elde edilen bulgular UFRS 16'nın işletmelerin sermaye ve kar yapılarında değişiklikler yarattı̆̆ını göstermektedir. Öz kaynak azalışı nedeniyle kiracı işletmenin defter değerinde düşme ortaya çıkmaktadır. Buna karşın esas faaliyet karlılığında ve faiz, vergi ve amortisman öncesi karda artış yaratarak firmaya serbest nakit akışlarını artırmaktadır. Diğer unsurlar sabit kalmak üzere bu durum, yüksek hacimde faaliyet kiralaması yapılan sektörlerdeki işletmelerin piyasa değeri/defter değeri oranlarının yükselmesine neden olacaktır. Ayrıca, diğer önemli bir etki işletmelerin riskliliği üzerinde ortaya çıkmaktadır. Finansal kaldıraç oranları ve likidite oranlarındaki artış nedeniyle kiracı işletmelerin hem kısa hem de uzun vadeli finansal risklilikleri artmaktadır. Varlık devir hızı oranındaki azalış ise, UFRS 16'göre düzenlenen finansal tablolar itibariyle işletmelerin varlık etkinliğinin düşük görünmesine yol açmaktadır.

\section{Kaynaklar}

Aktaş, R., Karğın, S., ve Arıcı, N.D. (2017). Yeni Kiralamalar Standardı UFRS 16'nın Getirdiği Yenilikler ve İşletmelerin Finansal Tablolarına ve Finansal Oranlarına Olası Etkilerinin Değerlendirilmesi. İşletme Araştırmaları Dergisi, 9(4), 858-881.

Magli, F., Nobolo, A. and Ogliari, M. (2018). The Effects on Financial Leverage and Performance: The IFRS 16, International Business Research, 11(8), 76-89.

Morales-Díaz, J., and Zamora-Ramírez, C. (2018). The impact of IFRS 16 on key financial ratios: a new methodological approach. Accounting in Europe, 15(1), 105-133.

Sacarin, M. (2017). IFRS 16 "Leases"-consequences on the financial statements and financial indicators. The Audit Financiar journal, 15(145), 114-114.

TFRS 16 (2018). 16 numaralı Kiralamalar Türkiye Finansal Raporlama Standardı. Kamu Gözetimi Muhasebe ve Denetim Standartları Kurumu.

https://www.kgk.gov.tr/Portalv2Uploads/files/Duyurular/v2/TFRS/TFRS_16.pdf (Erişim tarihi: 12 Ocak 2020).

UFRSEA (2016). Effects Analysis International Financial Reporting Standard 16 Leases, UFRS, January 2016. https://www.UFRS.org/-/media/project/leases/UFRS/published-documents/UFRS16-effectsanalysis.pdf (Erişim tarihi: 18 Şubat 2020).

Wong, K. and Joshi, M. (2015). The impact of lease capitalisation on financial statements and key ratios: Evidence from Australia. Australasian. Accounting, Business and Finance Journal, 9(3), 27-44. 